\title{
Potential Clue Towards the Association of Fish Intake/PPARGC1A Gene/Immune Status Among Non-Obesity-Family-History Overweight Youth: A Case Report and Update from a Prospective Study
}

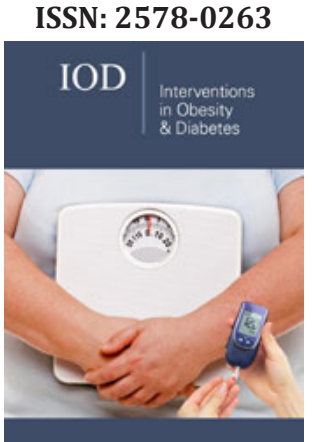

*Corresponding author: Xin Zhang, Department of Maternal, Child and Adolescent Health, School of Public Health, School of Basic Medical Sciences, Tianjin, China

Submission: 傮 February 05, 2020

Published: 想February 12, 2020

Volume 3 - Issue 4

How to cite this article: Juan Xie, Fei $\mathrm{Wu}$, Yongmei Li, Bei Sun, Xinyue Zhi, et al. Potential Clue Towards the Association of Fish Intake/PPARGC1A Gene/Immune Status Among Non-Obesity-FamilyHistory Overweight Youth: A Case Report and Update from a Prospective Study. Interventions Obes Diabetes 3(4). IOD.000567.2020.

DOI: $10.31031 /$ IOD.2020.03.000567

Copyright@ Xin Zhang. This article is distributed under the terms of the Creative Commons Attribution 4.0 International License, which permits unrestricted use and redistribution provided that the original author and source are credited.

\section{Juan Xie ${ }^{1}$, Fei $\mathrm{Wu}^{2}$, Yongmei $\mathrm{Li}^{3}$, Bei Sun ${ }^{4}$, Xinyue $\mathrm{Zhi}^{1}$, Xin Zhang5* and Qing} $\mathrm{Gu}^{6 *}$

${ }^{1}$ Department of Epidemiology and Biostatistics, School of Public Health, and Tianjin Key Laboratory of Environment, Nutrition \& Public Health,Tianjin Medical University, Tianjin, China

${ }^{2}$ School of Public Health, Tianjin Medical University, Tianjin, China

${ }^{3}$ Department of Pathogen Biology, School of Basic Medical Sciences, Key Lab of Immune Microenvironment and Disease (Ministry of Education) Tianjin Medical University, Tianjin, China

${ }^{4}$ NHC Key Laboratory of Hormones and Development(Tianjin Medical University), Tianjin Key Laboratory of Metabolic Diseases, Tianjin Medical University Chu Hsien-I Memorial Hospital and Tianjin Institute of Endocrinology, Tianjin, China

${ }^{5}$ Department of Maternal, Child and Adolescent Health, School of Public Health, School of Basic Medical Sciences, Tianjin Medical University, Tianjin, China

${ }^{6}$ Tianjin Centers for Disease Control and Prevention, Tianjin, China

\section{Abstract}

We have already known that lipid metabolism homeostasis existed in children and adolescents would be associated with PPARGC1A methylation status then impact the onset or progress of many chronic diseases in adulthood. And fish intake could show impact on the mRNA and methylation for many genes, thus help to control lots of diseases. This case highlighted more fish intake might be involved in down regulating PPARGC1A methylation and help to correct overweight, also do good to improve immune status among youth.

Keywords: Dietary factor; PPARGC1A gene; Immune status; Overweight; Adolescent

Abbreviations: PPARGC1A: Peroxisome Proliferative Activated Receptor Gamma Coactivator 1A; CAMP: Cyclic Adenosine Monophosphate

\section{Background}

It is well known that PPARGC1A regulates the activities of CAMP response element binding protein and nuclear respiratory factors, permits the interaction with multiple transcription factors [1,2]. Apart from regulating the genes involved in energy metabolism, it may be also involved in lipid metabolism such as development of obesity, or onset/progress of chronic disease $[1,2]$. In controlling and preventing chronic disease, some studies suggested that diet determinants such as fish intake, could down-regulated the mRNA expression of several genes including inflammation-related ones and also the genes involved in glucose and cholesterol metabolism, showed direct or indirect association with PPARGC1A mRNA [3,4]. Moreover, PPARGC1A gene not only acts as transcription factor involved in adipocyte differentiation and glucose metabolism, it has also been implicated in modulating immune responses [5]. During the course of our ongoing prospective study focused on the homeostasis of lipid metabolism and the association between homeostasis and Methylation of PPARGC1A in children and adolescents, some incidental consequence revealed potential clues towards the association of fish intake/PPARGC1A expression/immune status among non-obesity-family-history overweight youth.

\section{Case Presentation}

The boy was 12-years-old (birthdate: 2002-04-22) when he was enrolled in our ongoing research towards the homeostasis of lipid metabolism and the association between 
homeostasis and Methylation of PPARGC1A in children and adolescents, whose age was just at the beginning of onset of puberty, and the boy was examined to be overweight in his age group. During the course of the following 5 years, apart from the main aim of the given research, we also found some interesting results: The boy changed the diet (habit) consciously (which might because of own awareness of overweight status, etc.) after the awareness of overweight status, and according improvement was detected in both the body shape and immune status. This case exhibited a perfect association towards the body shape/lipid metabolism/ immune progress and confirm the value of fish intake in improving health status of individuals suffered from homeostasis of lipid metabolism. The finding from this typical case offered a potential clue towards the association of fish intake/PPARGC1A expression/ immune status among non-obesity-family-history overweight youth, which suggested that more fish diet exposure might be a factor involved in the methylation of PPARGC1A gene decreasing and also related to immune improvement, especially sensitive to young people. The detail of the typical case was shown in Table 1.

Table1: Detail of the report case demographic.

\begin{tabular}{|c|c|c|c|c|c|c|}
\hline & $\begin{array}{l}\text { Baseline } \\
\text { (in 2014) }\end{array}$ & $\begin{array}{c}\text { Year 1 } \\
\text { (in 2015) }\end{array}$ & $\begin{array}{c}\text { Year } 2 \\
\text { (in 2016) }\end{array}$ & $\begin{array}{c}\text { Year } 3 \\
\text { (in 2017) }\end{array}$ & $\begin{array}{c}\text { Year } 4 \\
\text { (in 2018) }\end{array}$ & $\begin{array}{c}\text { Year } 5 \\
\text { (in 2019) }\end{array}$ \\
\hline Height $(\mathrm{cm})$ & 161 & 165 & 169 & 172 & 175 & 177 \\
\hline Weight(kg) & 58 & 63 & 63 & 64 & 64 & 63.5 \\
\hline $\mathrm{BMI}\left(\mathrm{kg} / \mathrm{m}^{2}\right)$ & 22.38 & 23.14 & 22.06 & 21.63 & 20.9 & 20.04 \\
\hline WHR & $0.79(69.80 / 88.70)$ & $0.78(72.65 / 92.65)$ & $0.78(73.00 / 93.05)$ & $0.78(72.50 / 93.00)$ & $0.77(72.00 / 93.50)$ & $0.75(70.00 / 93.00)$ \\
\hline Fish intake & $\begin{array}{l}\text { less than } 1 \text { time/ } \\
\text { week, } 1 \text {-2times/ } \\
\text { month }\end{array}$ & $\begin{array}{c}\text { more than } 2 \text { times/ } \\
\text { month }\end{array}$ & $\begin{array}{c}\text { more than } 2 \text { times/ } \\
\text { month }\end{array}$ & $\begin{array}{l}\text { more than } 3 \\
\text { times/month }\end{array}$ & $\begin{array}{c}\text { more than } 3 \text { times/ } \\
\text { month }\end{array}$ & $\begin{array}{l}\text { more than3 } \\
\text { times/month }\end{array}$ \\
\hline $\begin{array}{l}\text { Fast food intake } \\
\text { frequency }\end{array}$ & $\begin{array}{c}\text { more than3 times/ } \\
\text { week }\end{array}$ & $\begin{array}{c}\text { more than } 3 \text { times/ } \\
\text { week }\end{array}$ & $\begin{array}{l}\text { less than } 2 \text { times/ } \\
\text { week }\end{array}$ & $\begin{array}{c}\text { less than2 times/ } \\
\text { week }\end{array}$ & $\begin{array}{c}\text { less than2 times/ } \\
\text { month }\end{array}$ & $\begin{array}{c}\text { less than } 2 \text { times/ } \\
\text { month }\end{array}$ \\
\hline $\mathrm{SBP}(\mathrm{mmHg})$ & 119 & 117 & 114 & 115 & 115 & 117 \\
\hline $\mathrm{DBP}(\mathrm{mmHg})$ & 75 & 76 & 71 & 70 & 71 & 70 \\
\hline LDL-C(mmol/L) & 1.95 & 1.91 & 1.9 & 1.87 & 1.85 & 1.74 \\
\hline $\mathrm{TG}(\mathrm{mmol} / \mathrm{L})$ & 0.89 & 0.85 & 0.82 & 0.8 & 0.78 & 0.75 \\
\hline $\mathrm{TC}(\mathrm{mmol} / \mathrm{L})$ & 3.92 & 3.91 & 3.92 & 3.9 & 3.81 & 3.76 \\
\hline HDL-C(mmol/L) & 1.09 & 1.35 & 1.39 & 1.56 & 1.66 & 1.69 \\
\hline $\mathrm{FBG}(\mathrm{mmol} / \mathrm{L})$ & 4.89 & 4.55 & 4.59 & 4.63 & 4.5 & 4.43 \\
\hline $\begin{array}{l}\text { Blood sample } \\
\text { PPARGC1A meth- } \\
\text { ylation(\%) }\end{array}$ & 0.78 & 0.72 & 0.633 & 0.504 & 0.399 & 0.343 \\
\hline mRNA(AU) & 0.06 & 0.06 & 0.06 & 0.07 & 0.09 & 0.09 \\
\hline CD4count & 360 & 430 & 465 & 482 & 485 & 486 \\
\hline $\mathrm{CD} 4 / \mathrm{CD} 8$ & 1.4 & 1.7 & 1.6 & 1.7 & 1.8 & 1.8 \\
\hline
\end{tabular}

\section{Discussion}

Disorders which related with lipid metabolism homeostasis existed in children and adolescents, they could lead to PPARGC1A methylation increasing and finally become a risk factor for many chronic diseases in adulthood [6,7]. Also, as mentioned at the beginning, PPARGC1A regulating the genes involved in energy metabolism, lipid metabolism and many other activities related to chronic diseases $[1,2,8,9]$. On the other hand, fish intake, as one of the diet determinants in chronic disease controlling, could show impact on the mRNA and methylation [10-12]. In this manuscript, the analysis suggested us that more fish intake could involve in down regulating PPARGC1A methylation, and also help to improve immune status among overweight youth. In fact, apart from the typical case presented above. Another 16 boys and girls who changed their diet (habit) as the report case were also been analyzed, the result showed us the similar change or progress for their gene methylation and immune status. It is also worth mentioning that, all of the 17 cases here were non-obesity-familyhistory kids. Moreover, when considering the confounding of age or complex hormone associated with the special age group(onset of the puberty) in the typical case, same analysis was also conducted in a second age group individuals, which enrolled 19 elder young subjects(17-years-old at the baseline), and all the subjects were coming from the same study population. Together with a third study group, in which the subjects were 65 cases of middle-oldaged individuals. The comparison of results among them showed us that the elder youth group obtained a similar trend, while not so 
obvious association was found for the middle-old-aged individuals. In summary, the current case exhibited that more fish diet exposure might be a factor involved in the methylation of PPARGC1A gene and also related to immune improvement, especially sensitive to young people.

\section{Conclusion}

This case highlighted more fish intake might be involved in down regulating PPARGC1A methylation and help to correct overweight, also do good to improve immune status among youth.

\section{Acknowledgement}

Thanks for the support from National Natural Science Fountain of China, Youth Foundation,(The study on the homeostasis of lipid metabolism and the association between homeostasis and Methylation of PPARGC1A) (No. 81502828).

\section{References}

1. Zhang GM, Guo YX, Deng MT, Wan YJ, Deng KP, et al. (2019) Effect of PPARGC1A on the development and metabolism of early rabbit embryos in vitro. Mol Reprod Dev 86(11): 1758-1770.

2. Bhatta P, Bermano G, Williams HC, Knott RM (2019) Meta-analysis demonstrates Gly482Ser variant of PPARGC1A is associated with components of metabolic syndrome within Asian populations. Genomics 7543(19): 30399-30394.

3. Rundblad A, Holven KB, Bruheim I (2018) Effects of fish and krill oil on gene expression in peripheral blood mononuclear cells and circulating markers of inflammation: A randomised controlled trial. J Nutr Sci 7: e10.
4. Flachs P, Horakova O, Brauner P, Rossmeisl M, Pecina P, et al. (2005) Polyunsaturated fatty acids of marine origin upregulate mitochondrial biogenesis and induce beta-oxidation in white fat. Diabetologia 48(11): 2365-2375.

5. Tang D, Zhao YC, Qian D, Liu H, Luo S, et al. (2020) Novel genetic variants in HDAC2 and PPARGC1A of the CREB-binding protein pathway predict survival of non-small-cell lung cancer. Mol Carcinog 59(1): 104-115.

6. Zhang H, Tang K, Ma J, Zhou L, Liu J, et al. (2020) Ketogenesis-generated $\beta$-hydroxybutyrate is an epigenetic regulator of $\mathrm{CD}^{+} \mathrm{T}$-cell memory development. Nat Cell Biol 22(1): 18-25.

7. Langbein H, Shahid A, Hofmann A, Mittag J, Bornstein SR, et al. (2019) NADPH oxidase 4 mediates the protective effects of physical activity against obesity-induced vascular dysfunction. Cardiovasc Res.

8. Saremi L, Lotfipanah S, Mohammadi M, Hosseinzadeh H, Hosseini Khah Z, et al. (2019) Association between PPARGC1A single nucleotide polymorphisms and increased risk of nonalcoholic fatty liver disease among Iranian patients with type 2 diabetes mellitus. Turk J Med Sci 49(4): 1089-1094.

9. Oliveira TE, Castro É, Belchior T, Andrade ML, Chaves Filho AB, et al. (2019) Fish oil protects wild type and uncoupling protein 1-deficient mice from obesity and glucose intolerance by increasing energy expenditure. Mol Nutr Food Res 63(7): e1800813.

10. Yang CS, Kim JJ, Lee HM, Jin HS, Lee SH, et al. (2014) The AMPKPPARGC1A pathway is required for antimicrobial host defense through activation of autophagy. Autophagy 10(5): 785-802.

11. Llimona F, de Lima TM, Moretti AI, Theobaldo M, Jukemura J, et al. (2014) PGC-1 $\alpha$ expression is increased in leukocytes in experimental acute pancreatitis. Inflammation 37(4): 1231-1239.

12. Qi X, Zhang Y, Li J, Hou D, Xiang Y, et al. (2012) Effect of PGC-1 $\alpha$ on proliferation, migration, and transdifferentiation of rat vascular smooth muscle cells induced by high glucose. J Biomed Biotechnol. 